\title{
HUBUNGAN HIPERKOLESTEROLEMIA DENGAN OBESITAS PADA SISWA SMP EBEN HAEZAR MANADO
}

\author{
${ }^{1}$ Andrian Aldo Rantung \\ ${ }^{2}$ Adrian Umboh \\ ${ }^{2}$ Max F. J. Mantik
}

\author{
${ }^{1}$ Kandidat Skrispi Fakultas Kedokteran Universitas Sam Ratulangi Manado \\ ${ }^{2}$ Bagian Ilmu Kesehatan Anak Fakultas Kedokteran Universitas Sam Ratulangi Manado \\ Email: User_rr@rocketmail.com
}

\begin{abstract}
Hypercholesterolemia in children is a risk factor for cardiovascular disease. Obesity is one of the risk factors of hypercholesterolemia. Objective: This study aimed to determine the relation between hypercholesterolemia and obesity in Junior High School students. Methods: This study used an observational analytic designed with cross sectional approach by using consecutive sampling from November 2013 - January 2014. There were 50 Eben Haezar Junior High School students in this study, consisted of 30 students with Bझ̈percentile -95 CDC Curve and 20 students with BMI < percentile-95 CDC Curve. Data were analyzed using fisher's exact test. Result: Of the 30 samples with BMI $\geq$ percentile-95, there were 5 samples (17\%) had hypercholesterolemia. Of the 20 samples with BMI < percentile-95, there were none of them had hypercholesterolemia. Statistically, there is no relation between hypercholesterolemia and obesity ( $>0.05$ ). Conclusion: There is no relation between hypercholesterolemia and obesity in Eben Haezar Junior High school students.
\end{abstract}

Keywords: hypercholesterolemia, obese, children.

\begin{abstract}
Abstrak: Hiperkolesterolemia pada anak merupakan faktor risiko dari penyakit kardiovaskular. Obesitas merupakan salah satu faktor risiko penyebab hiperkolesterolemia. Tujuan penelitian: Penelitian ini bertujuan untuk mencari hubungan antara hiperkolesterolemia dengan obesitas pada siswa SMP. Metode: Penelitian ini menggunakan desain penelitian observasional analitik dengan rancangan cross sectional yang dilakukan dengan cara consecutive sampling dari bulan november 2013 - januari 2014. Sampel penelitian berjumlah 50 siswa SMP Eben Haezar manado yang terdiri dari 30 siswa dengan IMT $\geq$ persentile-95 kurva CDC dan 20 siswa dengan IMT < persentile-95 kurva CDC, dimana pada 50 sampel dilakukan pengukuran kadar kolesterol total. Data di analisa dengan fisher's exact test Hasil penelitian: Dari 30 sampel dengan IMT $\geq$ persentile -95, didapatkan 5 sampel (17\%) mengalami hiperkolesterolemia. Dari 20 sampel dengan IMT < persentile-95, tidak didapatkan hiperkolesterolemia. Secara statistik tidak ditemukan hubungan antara hiperkolesterolemia dengan obesitas $(\mathrm{p}>0.05)$. Simpulan: Tidak terdapat hubungan antara hiperkolesterolemia dengan obesitas pada siswa SMP Eben Haezar Manado.
\end{abstract}

Kata Kunci: hiperkolesterolemia, obesitas, anak.

Hiperkolesterolemia didefinisikan sebagai kadar kolesterol plasma yang melebihi ambang batas normal, adalah faktor risiko yang kuat dari penyakit kardiovaskular. ${ }^{1}$ beberapa faktor yang berada diluar kendali dapat meningkatkan resiko hiperkolesterol- emia. Faktor ini termasuk umur, jenis kelamin, dan keturunan. Tapi, ada beberapa faktor risiko yang dapat diubah. Contohnya diet yang tidak sehat, kelebihan berat badan dan kurang olah raga. ${ }^{2}$ Kadar kolesterol total orang dewasa dinyatakan tinggi apabila 
mencapai nilai $240 \mathrm{mg} / \mathrm{dl}$ atau lebih. ${ }^{3}$ Sedangkan pada anak-anak dan remaja, nilai kolesterol total yang mencapai nilai 200 $\mathrm{mg} / \mathrm{dl}$ atau lebih sudah dinyatakan tinggi. ${ }^{4}$

Berdasarkan survei yang dilakukan pada tahun 2008 , terdapat $35,1 \%$ penduduk Indonesia berusia 25 tahun keatas yang memiliki nilai kolesterol total $190 \mathrm{mg} / \mathrm{dl}^{5}$ Pada survei yang dilakukan di SDK Fr. Don Bosco Manado pada tahun 2001, terdapat 35,9\% anak usia 10-12 tahun yang memiliki nilai kolesterol total $200 \mathrm{mg} / \mathrm{dl}$ atau lebih. ${ }^{6}$

Obesitas merupakan salah satu faktor resiko dari hiperkolesterolemia. ${ }^{2}$ Anak-anak di negara berpendapatan rendah-menengah lebih rentan terhadap kekurangan nutrisi. Di saat yang sama, mereka terpapar dengan makanan tinggi lemak, tinggi gula, tinggi garam, padat energi namun kurang mikronutrien, yang cenderung rendah biaya. Pola diet ini disertai dengan rendahnya aktifitas fisik, berdampak pada peningkatan angka obesitas anak sementara masalah kekurangan nutrisi belum teratasi. ${ }^{7}$ Anak yang menderita obesitas beresiko lebih tinggi untuk mengalami obesitas saat dewasa. ${ }^{8}$

Anak dan remaja (2-20 tahun) dinyatakan obesitas ditentukan dengan perhitungan persentil berdasarkan umur dan jenis kelamin. Anak dengan IMT persentil ke-95 atau lebih digolongkan sebagai anak dengan obesitas. ${ }^{9}$ Di Seluruh dunia, berdasarkan survei yang dilakukan setelah tahun 1990, terdapat 2-3\% anak (usia 5-17 tahun) yang mengalami obesitas. ${ }^{10}$ Di Indonesia, prevalensi obesitas pada anak usia 6-15 tahun meningkat dari 5\% di tahun 1990 menjadi $16 \%$ tahun $2001 .^{11}$ Berdasarkan survei yang dilakukan pada tahun 2004-2005 di beberapa sekolah menengah pertama di
Manado, terdapat 28\% anak dengan obesitas berumur 11-15 tahun yang memiliki kadar kolesterol total $200 \mathrm{mg} / \mathrm{dl}$ atau lebih. ${ }^{12}$

\section{METODE PENELITIAN}

Penelitian ini bersifat observasional analitik dengan rancangan cross sectional yang dilaksanakan pada bulan November 2013 sampai Januari 2014. Populasi dalam penelitian ini adalah siswa kelas 1 - 3 SMP Eben Haezar Manado. Pengambilan sampel menggunakan metode consecutive sampling. Kriteria inklusi adalah siswa yang terdaftar sebagai siswa SMP Eben Haezar Manado dan bersedia menjadi responden. Sampel terdiri dari 30 siswa dengan IMT = >persentile-95 dan 20 siswa dengan IMT = $<$ persentile-95, menurut umur dan jenis kelamin dari CDC.

Nilai kolesterol diperiksa di laboratorium Dinas Kesehatan Manado. Pengambilan darah dan pengukuran dilakukan oleh pegawai Dinas Kesehatan Manado. Klasifikasi kadar kolesterol total pada anak adalah; $<170 \mathrm{mg} / \mathrm{dL}$ : normal, 170-199 mg/dL: batas normal, $\geq 200 \mathrm{mg} / \mathrm{dL}$ : hiperkolesterolemia.

Data dianalisa dengan SPSS (versi 17) dengan menggunakan Fisher's Exact Test. Nilai P yang kurang dari 0.05 merupakan hasil yang secara statistik berhubungan.

\section{HASIL PENELITIAN}

Penelitian ini dilakukan pada siswa dan siswi yang bersekolah di SMP Kristen Eben Haezar Manado. Total jumlah sampel yang diteliti adalah sebesar 50 sampel, yang terdiri dari 30 anak yang mengalami obesitas dan 20 anak yang non obesitas.

Tabel 1. Distribusi peningkatan kadar kolesterol berdasarkan jenis kelamin

\begin{tabular}{llccc}
\hline $\begin{array}{l}\text { Jenis } \\
\text { Kelamin }\end{array}$ & Status Gizi & Jumlah & Normal & Hiperkolesterolemia \\
\hline Laki-laki & Obesitas & 13 & $10(77 \%)$ & $3(23 \%)$ \\
& Non-obesitas & 4 & $4(100 \%)$ & $0(0 \%)$ \\
Perempuan & Obesitas & 17 & $15(88 \%)$ & $2(12 \%)$ \\
& Non-obesitas & 16 & $13(100 \%)$ & $0(0 \%)$ \\
Total & & 50 & 45 & 5 \\
\hline
\end{tabular}


Rantung, Umboh, Mantik; Hubungan Hiperkolesterolemia dengan Obesitas...

Tabel 2. Hasil pengukuran kadar kolesterol

\begin{tabular}{ccccc}
\hline Sampel & Jumlah & Normal & hiperkolesterolemia & P Value \\
\hline Obesitas & 30 & $25(83 \%)$ & $5(17 \%)$ & \multirow{0,075}{*}{ Non Obesitas } \\
Jumlah & 50 & $20(100 \%)$ & $0(0 \%)$ & \\
\end{tabular}

Pada Tabel 1 dapat dilihat bahwa dari 18 siswa laki-laki yang obesitas, terdapat 10 siswa (77\%) yang memiliki kadar kolesterol normal dan 3 siswa (23\%) yang mengalami hiperkolesterolemia. Sedangkan dari 4 siswa laki-laki yang tidak mengalami obesitas, seluruhnya (100\%) memiliki kadar kolesterol normal. Dari 17 siswi perempuan yang mengalami obesitas, terdapat 15 siswi (88\%) yang memiliki kadar kolesterol normal dan 2 siswi (12\%) yang mengalami hiperkolesterolemia. Sedangkan dari 16 siswi perempuan yang tidak mengalami obesitas, terdapat 16 siswi (100\%) yang memiliki kadar kolesterol normal.

Pada Tabel 2 dapat dilihat bahwa dari 30 sampel yang mengalami obesitas terjadi hiperkolesterolemia sebanyak 5 sampel dan yang tidak terjadi hiperkolesterolemia sebanyak 25 sampel, sedangkan yang non obesitas dari 20 sampel menunjukkan bahwa tidak ada yang terjadi hiperkolesterolemia.

Dari hasil uji fisher's exact, didapatkan nilai sig. $>0.05$ yang menunjukan bahwa secara statistik tidak ada hubungan antara hiperkolesterolemia dengan obesitas.

\section{BAHASAN}

Dari 30 anak yang mengalami obesitas yang diteliti, ditemukan 5 anak mengalami hiperkolesterolemia atau sebanyak 17\%, hasil ini lebih rendah dari penelitian oleh Tangkilisan et $\mathrm{al}^{12}$ yang dilakukan di manado, dimana didapatkan $28 \%$ siswa smp yang mengalami obesitas menderita hiperkolesterolemia. Dari 20 anak yang tidak mengalami obesitas, tidak ada yang mengalami hiperkolesterolemia. Keadaan hiperkolesterolemia yaitu dimana nilai kadar kolesterol anak berada pada nilai 200 atau lebih.

Dari 50 sampel yang diuji, baik obesitas dan non obesitas, terdapat 5 sampel (10\%) yang mengalami hiperkolesterolemia, hasil ini lebih tinggi dari penelitian oleh Fesharakinia et $\mathrm{al}^{13}$ yang dilakukan di Iran dimana didapatkan 3\% anak yang mengalami hiperkolesterolemia.

Dari hasil uji fisher's exact, didapatkan nilai $\mathrm{p}>0.05$ yaitu 0,075 yang menunjukan bahwa secara statistik tidak ada hubungan antara hiperkolesterolemia dengan obesitas pada siswa SMP Eben Haezar Manado. Hasil ini berbeda dengan hasil penelitian Wulur et $\mathrm{al}^{6}$ yang dilakukan di manado dimana didapatkan hubungan antara hiperkolesterolemia dengan gizi berlebih pada anak. Namun, hasil ini sesuai dengan penelitian oleh Hidayati et $\mathrm{al}^{14}$ yang tidak mendapatkan hubungan antara kadar kolesterol dengan status gizi anak.

Walaupun secara statistik tidak terdapat hubungan antara hiperkolesterolemia dengan obesitas pada siswa SMP Eben Haezar Manado, namun terdapat perbedaan tingkat kolesterol antara siswa obesitas dan yang non-obesitas, dimana rata-rata kadar kolesterol siswa obesitas adalah 171,5 mg/dl dan siswa non-obesitas adalah 146,5 mg/dl. Pada SMP Eben Haezar manado, hiperkolesterolemia hanya terjadi pada sampel yang mengalami obesitas, yaitu 5 (17\%) dari 30 sampel yang diteliti. Dapat dilihat bahwa peningkatan kadar kolesterol lebih banyak terjadi pada sampel yang mengalami obesitas, dan sampel yang mengalami obesitas memiliki risiko yang lebih tinggi untuk mengalami hiperkolesterolemia dibanding sampel yang tidak mengalami obesitas.

Hiperkolesterolemia pada obesitas disebabkan oleh tingginya kadar FFA pada 
subjek yang memiliki jaringan adiposa yang lebih tebal sehingga meningkatkan kadar produksi trigliserida akibat aliran FFA yang meningkat pada hati, dimana trigliserida akan memicu pembentukan VLDL yang berlebihan dimana dapat menyebabkan tingginya jumlah LDL di aliran darah, hingga dapat meningkatkan kadar kolesterol secara keseluruhan. $^{15}$

Tidak adanya hubungan antara hiperkolesterolemia dan obesitas pada siswa SMP Eben Haezar manado bisa disebabkan oleh cukupnya aktifitas fisik dan olahraga serta diet yang rendah kolesterol, serta faktorfaktor lain yang didapatkan memiliki hubungan dengan kadar kolesterol pada anak, dimana pada hasil penelitian oleh Hidayati et $\mathrm{al}^{14}$, didapatkan hubungan antara kadar asupan karbohidrat dan lemak dengan peningkatan kadar kolesterol pada anak dan pada penelitian yang dilakukan oleh Tangkilisan et $\mathrm{al}^{12}$ mendapatkan hubungan antara kadar kolesterol dengan jenis kelamin, konsumsi kalori, kebiasaan memakan makanan siap saji, aktifitas fisik dan kebiasaan menonton TV serta durasi tidur anak yang menderita obesitas.

\section{SIMPULAN}

Pada penelitian ini ditemukan bahwa tidak ada hubungan antara hiperkolesterolemia dengan obesitas pada siswa SMP Eben Haezar Manado.

\section{DAFTAR PUSTAKA}

1. Stapleton PA, Goodwill AG, James ME, Brock RW, Frisbee JC. Hypercholesterolemia and microvascular dysfunction: interventional strategies. J Inflamm (Lond) 2010.7: 54.

2. CDC. Know The Facts About High

Cholesterol. Diunduh 22 september 2013.

Diakses di :

http://www.cdc.gov/cholesterol/docs/Consu merEd_cholesterol.pdf

3. Jellinger PS, Smith DA, Mehta AE, Ganda O, Handelsman Y, Rodbard HW, et al. guidelines for management of dyslipidemia and prevention of atherosclerosis. AACE Lipid And Atherosclerosis Guidelines, Endocr Pract. 2012.18: 10.
4. Kwiterovich PO. Recognition and Management of Dyslipidemia in Children and Adolescents. J Clin Endocrinol Metab.2008.93:4200-4209.

5. World Health Organization. Noncommunicable diseases country profiles 2011.93.

6. Wulur FH, Pieter RDB. Association between serum cholesterol levels and nutritional status in school children aged 1012 years. Paediatrica Indonesiana, 2003.43 : 73-76.

7. World Health Organization. Overweight and Obesity Fact Sheet.2011. Diunduh 19 september 2013. Diakses di :

http://www.searo.who.int/entity/noncommu nicable_diseases/media/non_communicable _diseases_obesity_fs.pdf

8. CDC. Health effects of childhood obesity. Diunduh 10 oktober 2013. Diakses di : http://www.cdc.gov/healthyyouth/obesity/fa cts.htm

9. American Heart Association. Understanding childhood obesity. An Epidemic of

Excess (2010). Diunduh 19 september 2013. Diakses di : http://www.heart.org/idc/groups/heartpublic/@wcm/@fc/documents/downloadabl e/ucm_304175.pdf

10. Lobstein T, Baur L, Uauy R. Obesity in children and young people: a crisis in public health. Obesity reviews 2004.5: 4-85.

11. Sartika RAD. Faktor Risiko Obesitas pada Anak 5-15 tahun di Indonesia. Makara Kesehatan.2011.15: 37-43.

12. Tangkilisan AH, Akune K. Some factors related to lipid profile in obese children at junior high schools in Manado. Paediatrica Indonesiana 2007.47: 167.

13. Fesharakinia A, Zarban A, Sharifzadeh GR. Lipid profiles and prevalence of dyslipidemia in schoolchildren in south Khorasan Province, eastern Iran. Arch Iran Med 2008.11: 598-601.

14. Hidayati SN, Hadi H, Lestariana W. Hubungan asupan zat gizi dan indeks masa tubuh dengan hiperlipidemia pada murid SLTP yang obesitas di Yogyakarta. Sari Pediatri 2006.8: 25-31.

15. Klop B, Elte JWF, Cabezas MC. Dyslipidemia in Obesity : Mechanism and Potential Targets. Nutrients. 2013.5. : 12191228. 